Florida International University FIU Digital Commons

FIU Electronic Theses and Dissertations

University Graduate School

3-30-2017

\title{
Reimagining Movements: Towards a Queer Ecology and Trans/Black Feminism
}

Gabriel Benavente

gbena002@fiu.edu

DOI: 10.25148 /etd.FIDC001788

Follow this and additional works at: https://digitalcommons.fiu.edu/etd

Part of the African American Studies Commons, American Literature Commons, American Politics Commons, Continental Philosophy Commons, Environmental Studies Commons, Feminist Philosophy Commons, Lesbian, Gay, Bisexual, and Transgender Studies Commons, Literature in English, North America, Ethnic and Cultural Minority Commons, Other Ecology and Evolutionary Biology Commons, and the Religion Commons

\section{Recommended Citation}

Benavente, Gabriel, "Reimagining Movements: Towards a Queer Ecology and Trans/Black Feminism" (2017). FIU Electronic Theses and Dissertations. 3186.

https://digitalcommons.fiu.edu/etd/3186

This work is brought to you for free and open access by the University Graduate School at FIU Digital Commons. It has been accepted for inclusion in FIU Electronic Theses and Dissertations by an authorized administrator of FIU Digital Commons. For more information, please contact dcc@fiu.edu. 


\title{
FLORIDA INTERNATIONAL UNIVERSITY
}

Miami, Florida

\section{REIMAGINING MOVEMENTS: TOWARDS A QUEER ECOLOGY AND TRANS/BLACK FEMINISM}

\author{
A thesis submitted in partial fulfillment of the \\ requirements for the degree of \\ MASTER OF ARTS \\ in \\ ENGLISH \\ by \\ Gabriel Alexis Benavente
}


To: Dean Michael R. Heithaus

College of Arts, Sciences, and Education

This thesis, written by Gabriel Alexis Benavente, and entitled Reimagining Movements: Towards a Queer Ecology and Trans/Black Feminism, having been approved in respect to style and intellectual content, is referred to you for judgment.

We have read this thesis and recommend that it be approved.

$\begin{array}{r}\hline \text { Nandini Dhar } \\ \hline \text { Heather Russell } \\ \hline \text { Jason Pearl } \\ \hline \text { Martha Schoolman, Major Professor }\end{array}$

Date of Defense: March 30, 2017

The thesis of Gabriel Alexis Benavente is approved.

Dean Michael R. Heithaus

College of Arts, Sciences and Education

Andrés G. Gil

Vice President for Research and Economic Development

and Dean of the University Graduate School

Florida International University, 2017 


\section{DEDICATION}

For all queer, trans, and people of color who have felt excluded from social and environmental justice movements. I do not pretend to hold the answers to solving legacies of oppressive systems, but I do hope that this thesis can work towards our collective liberation. 


\section{ACKNOWLEDGMENTS}

Throughout my journey at Florida International University a plethora of people have supported me in times of despair. This community of people have molded, challenged, and nourished me in my development as a scholar. The warmth, compassion, and care from my Miamian home will sustain me, as I proceed to venture onto unknown territories.

My parents, Elda and Rafael Benavente, have sacrificed their livelihoods to give me the opportunity to succeed. They have taught me the value of hard work, and rising above the challenges that dehumanize my existence as an immigrant. Along with them, I thank my sister Alexa Benavente who has been a great source of brightness, compassion, and support. I must also acknowledge my partner Connor Hobart, as well as my best friend throughout graduate school Jorge Cartaya. Both of you inspire me to keep dreaming. Thank you.

I also thank the staff of 107 Coffee and Dessert, who have provided me with nourishment at a time when eating often became a matter of last priority. You have reminded me that the best memories are often shared with friends at the dinner table. Thank you.

To my professors and mentors, Martha Schoolman, Heather Russell, Nandini Dhar, and Jason Pearl: you have been my pillar of support throughout my time at FIU. Thank you for recognizing the value and urgency of my work, even in times that I've felt hopeless. Your knowledge, guidance, and encouragement will carry on with me in my future as a scholar. Along with them, I also owe my gratitude to Professors Ana Luzscynska, Maneck Daruwala, Michael Patrick Gillespie, Donna Weir-Soley, Carmela 
McIntire, and Cindy Chinelly—it is through their support that I am able to stand proud in being the first person in my family to attain the riches of higher education. Thank you. I also thank the many friends I've met throughout my experiences as a graduate student. I extend my gratitude towards Jorge Cartaya, Raquel Vallecillo, Laura Aguirre, Irene Inatty, Mariane Stanev, David Frisch, Stephanie Selander, Matthew Solderblom, T.C. Jones, Allison Sardinas, Zina Hutton, Marlene Tovar, Yannel Celestrin, Rayna Susenko, and Farah Diba. I hold dearly to the treasures, adventures, and love we have shared with one another. Thank you.

Thank you for believing in Gabby and the woman that I aspire to be. Your presence will keep me grounded in achieving my goals. 


\section{ABSTRACT OF THE THESIS \\ REIMAGINING MOVEMENTS: TOWARDS A QUEER ECOLOGY AND \\ BLACK/TRANS FEMINISM}

by

Gabriel Alexis Benavente

Florida International University, 2017

Miami, Florida

\section{Professor Martha Schoolman, Major Professor}

This thesis seeks to bridge feminist and environmental justice movements through the literature of black women writers. These writers create an archive that contribute towards the liberation of queer, black, and transgender peoples.

In the novel Parable of the Talents, Octavia Butler constructs a world that highlights the pervasive effects of climate change. As climate change expedites poverty, Americans begin to blame others, such as queer people, for the destruction of their country. Butler depicts the dangers of fundamentalism as a response to climate change, highlighting an imperative for a movement that does not romanticize the environment as heteronormative, but a space where queers can flourish.

Just as queer and environmental justice movements are codependent on one another, feminist movements cannot be separate from black and transgender liberation. This thesis will demonstrate how writers, such as Audre Lorde, Toni Morrison, Angela Davis, and Janet Mock, help establish a feminism that resists the erasure of black and transgender people. 


\section{TABLE OF CONTENTS}

SECTION

PAGE

Introduction:

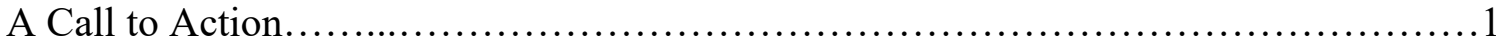

Section 1:

Queering Ecology through Octavia Butler's Parable of the Talents...................... 3

Section 2:

Decolonizing Feminisms: Lorde, Mock, Morrison, and Reimagining Womanhood......30

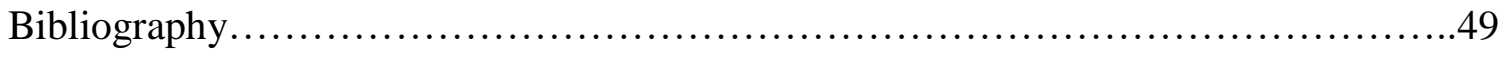


Introduction

A Call to Action

A movement that is grounded on collective liberation, as opposed to toxic individualism, recognizes the interconnected value of all beings beyond their own singular lives. The collective provides solidarity that acknowledges the materiality of systematic oppression, which leads to the devaluation of people. It is not limited to mere understanding of concepts, but rather it calls for actions, such as the ones Lauren Olamina takes in Octavia Butler's Parable series when she sees her community is endangered by climate change and social injustice. In order to survive, Lauren has to continuously adapt to varying forms of perpetual violence, losing loved ones along her journey. In spite of these challenges, Lauren's desire to shape a movement that extends beyond herself is seen when she fearlessly fights for the conservation of her community. The environmental justice movement that Octavia Butler's writing exemplifies is not prescriptive, as it does not claim an objective truth. Instead, it recognizes how narratives that establish authority are capable of reproducing systematic oppression. These values shape a movement that listens as opposed to imposing, and gives power back to marginalized groups that have had their voices silenced by oppressive ideologies. Within these groups exist many LGBTQ people, many which have traditionally been silenced not only from social institutions, but from movements that would otherwise appear inclusive. Inspired by Octavia Butler's desire for collective solidarity, I have been thinking of ways in which activism accessible can be made accessible to varying audiences. How can we, as Angela Davis argues, "find reservoirs of hope and optimism" (49) in communities otherwise fragmented by oppression. I see potential in both literature 
and activism to be intertwined in the struggle towards providing alternative solutions that dismantle toxic structures, thus creating alternative ways of living that embody principles of collective liberation. In particular, I seek to highlight how Octavia Butler reimagines the field of ecocritical studies, and posits a movement that is just towards both queers and the environment.

Similar to Butler's reimagining of a movement that is both queer and ecocritical, I look to writers like Audre Lorde, Janet Mock, and Toni Morrison in looking towards ways in which feminisms can acknowledge difference and assure liberation for all people. I want to draw attention to how their feminisms speak to women of color and transgender women, groups which have historically been ostracized by a monolithic feminist movement. In particular, I intend to demonstrate how Morrison's depiction of womanhood in Beloved challenges the idea that womanhood be defined in terms of white, middle and upper class women, reclaiming identity in a world where enslaved blacks were deprived of their humanity and the power to establish themselves as people. Similarly, I make the case that Lorde defies a womanhood defined in terms of white, upper and middle class women by confronting a feminism that claims to be fighting for the rights of women, but operates within the apparatus of white supremacy and the exclusion of women of color. In highlighting how abiding by a feminism that does not account for difference, and seeks to create a hierarchy of female experience is oppressive, I argue that both Morrison and Lorde hold contemporary urgency in that they do not only provide a framework for an intersectional feminist analysis, but that their analysis can also speak to the experiences of other groups that have been traditionally excluded within feminism, such as transgender women. Using Janet Mock's memoir Redefining Real: My 
Path to Womanhood, Identity, Love \& So Much More, I will emphasize how Morrison and Lorde's understanding of difference, and their acknowledgement that there are multiple experiences that build womanhood, can be nourishing towards transgender women. In particular, black transgender women like Mock, who often have their right to establish identity invalidated.

By looking at the texts of Butler, Mock, Morrison, and Lorde, I will make the argument that these texts provide an activist archive for groups that have been excluded by environmental and feminist movements. By decentering privileged groups from holding authority, and allowing for marginalized groups to speak from their own experiences, power structures that demean others can be dismantled.

\section{Section 1: Queering Ecology through Octavia Butler's Parable of the Talents}

Although climate change is a global phenomenon, its material impacts will be felt by certain peoples, such as black, indigenous, and queer, disproportionately. In scientific terms, climate change is a natural consequence, but nevertheless a process expedited by humans that will result in increased droughts, poverty, rising seas, and many other dire consequences. In light of these facts, Critic Rob Nixon invites us to reconceptualize our understanding of climate change by not only highlighting its potential for destruction, but as an act of violence committed by a privileged few upon a less-privileged many. An example of climate change as violent is demonstrated by the fact that rich nations are pumping carbon dioxide into the atmosphere, rapidly increasing floods in island nations whose residents do not have the privileges of migration. In understanding why sinking islands constitute examples of climate violence, Nixon argues that "it is crucial to 
"complicate conventional assumptions about violence as a highly visible act that is newsworthy because it is event focused, time bound, and body bound" (3). Nixon's text is necessary in that it addresses how the violence of climate change is often invisible, as its consequences are perceived to be distant, rather than interwoven in our present.

Furthermore, Nixon highlights how systems of oppression, such as white supremacy, are not only accelerated by climate change, but reinforced by people who should presumably be conscious of the environment. Nixon, for example, speaks of the "rich-nation environmentalists who were campaigning against garbage dumps and industrial effluent that they condemned as health threats and found aesthetically offensive" (2), who then proceed to send these pollutants to the Global South. Nixon's words resonate with Nigerian poet Ken-Saro Wiwa, who states that in exchange for Western prosperity, multinational corporations commit violence against Nigerian communities. Wiwa writes that in Nigeria, "[M]en, women and children die unnoticed, flora and fauna are threatened, the air is poisoned, waters are polluted, and finally, the land itself dies" (284). In recognizing the destruction of Nigerian land by multinational corporations as an act of violence, Wiwa encourages storytellers to break the silences that allow for the propagation of these injustices, stating that the writer must not "merely Xray society's weaknesses" (19), but must "actively shape its present and its future" (19). By highlighting how the pollutants that accelerate climate change disproportionately affect the Global South, Nixon and Wiwa contribute to an archive that calls for climate justice. Both writers challenge environmentalists, artists, and scholars to examine ways in which movements can work towards protecting the land, and assuring liberation for all peoples. 
Although both Nixon and Wiwa have helped to foster an increased awareness of climate change as violence against subjugated populations, however, academic and literary texts which connect climate violence against LGBTQ people are not as plentiful ${ }^{1}$. In accounting for the archival scarcity that demonstrates the connection between LGBTQ people and their environment, there is a material urgency for an environmental justice movement that is more inclusive of queer experiences. Additionally, environmental justice movements need to acknowledge that the romanticization of nature, which is an ideology that is still privileged within environmental social movements, often reinforces heteronormativity. In speaking about the romanticization of nature, I refer to what William Cronon argues to mean reinforcements of environmental essentialism. Cronon highlights a history within the United States of essentializing nature as a patriotic entity that represents America, as he states;

But the romantic sublime was not the only cultural movement that helped transform wilderness into a sacred American icon during the nineteenth century. No less important was the powerful romantic attraction of primitivism, dating back at least to of that the best antidote to the ills of an overly refined and civilized modern world was a return to simpler, more primitive living. In the United States, this was embodied most strikingly in the national myth of the frontier... Seen in this way, wild country became a place not just of religious redemption but of national renewal, the

\footnotetext{
${ }^{1}$ When germinal theorist Timothy Morton published his guest column Queer Ecology in 2010, he noted that the field of queer ecology “doesn't quite exist (273)," signaling a presupposed disconnect between the two fields.
} 
quintessential location for experiencing what it meant to be an American.

Given the predominant influence of colonial Christianity in the United States, both anthropocentric ownership of the environment and heteronormative understandings of gender and sexuality became normative. The land was assigned an essential, Christianized American value through the process of colonization. Therefore, Heteronormativity, which is defined by theorists Karen Lovaas and Mercilee Jenkins as "the principles of order and control that position heterosexuality as the cornerstone of the American sex/gender system and obligate the personal construction of sexuality and gender in terms of heterosexual norms" (98), became entrenched in the construction of American Nature. Nature became reducible to essentialist biopolitics, leading to what Greta Gaard argues to be a form of heterocentrism that "charges queer sexualities with being against Nature" (117). As a result, because of the privileging of Anthropocentric understandings of nature, nature became a dominant force in justifying the abnormality of queer existence. The impositions of heteronormativity are therefore violent, because they invalidate identities that fall outside the paradigm of what is constructed as "natural" gender and sexuality. Natural romanticism, in turn, helps drive heteronormative violence because it assigns an inherent, often heteronormative identity to how nature should operate. In other words, the history of American environmental colonization and the imposition of heteronormativity as norm are unextractable from one another.

Examples of heteronormative violences that are validated by natural romanticism can be demonstrated through the veneration of religious figureheads like Pope Francis. Pope Francis has recently received attention for revitalizing a tradition of environmental 
consciousness within Christianity, garnering praise for speaking out at a time when climate action is urgent. In an article titled "How Pope Francis Helped Awakened a Deep Religious Tradition for Care for the Environment" for the Washington Post, Environmental Historian Mark Stoll argues that "The pantheon of great heroes of environmentalism is thoroughly Protestant — Henry David Thoreau, Theodore Roosevelt, John Muir, Aldo Leopold, David Brower, Rachel Carson, Edward Abbey". Stoll then proceeds to invite his audience to see the various ways in which Catholics also hold environmentalism as a core value. Stoll venerates Pope Francis, and highlights a tradition of Catholic environmentalism, stating that "In addition to environmental justice, other Catholics have advocated reverence for nature as the creation of God, which they see as the necessary foundation for environmental progress. Since the late 20th century, Catholic priests, friars and theologians, not Protestant clergy, have produced the popular works on God's presence in creation". Conspicuously absent from such acclamations of Pope Francis and others who uphold Christian environmentalism, however, are the various ways in which nature has been romanticized by these traditions to uphold oppressive ideologies. Let us consider, for example, that shortly after Pope Francis received applause for his stance on climate change, he proceeded to establish transgender identity as "ideological colonization," boldly proclaiming that "it's against nature," and that such identities will lead to the destruction of the heterosexual family union (Newsome). In short, according to the Catholic environmentalism of Pope Francis and many others within the Catholic Church hierarchy, the "queer" stands in opposition to nature as God intended. The formulation of Catholic environmentalism relies on a 
Natural Romanticism that posits environmentalism against queer people, and has been misguidedly used to enact heteronormative violence.

Similarly to Pope Francis, examples of natural romanticism can be found throughout several literary texts. These instances of natural romanticism, for example, can be found in Sir Thomas More's novel Utopia, in which More envisions a community grounded on the principles of religious tolerance. Yet in imagining a seemingly liberatory world, More proceeds to define nature as essentially heteronormative. More states that "[N]ature, like a most indulgent mother, has placed her best gifts out in the open, like air, water and the earth itself; vain and unprofitable things she has hidden away in remote places" (60). More's construction of world, therefore, falls back on essentializing nature not only as presupposed to exploration, or to put in succinct terms colonization, but as holding an inherent female identity that complements the world of man. To think of the environment, as other than male and female separate spheres, just as Pope Francis would posit, then becomes unthinkable. The environment that More envisions, therefore does not speak to the queerness of the world, but to the naturalized heteronormative order established by Christian ideology. In reconciling frustrations towards a literary and ideological archive that reinforce heteronormativity, texts that do not prescribe the function of the world as heteronormativity are imperative in combating hatred of the queer.

Recent work by scholars such as Timothy Morton and Kevin Hutchings has begun to highlight the problematic relation between queer identity and a romanticized nature. As illustrated by Hutchings, the romanticization of nature acts as an example of heteronormativity, because it relies on a nature that is "pre-ideological, untouched in its 
materiality by the realm of human ideology and practice" (Hutchings 10). Materially, that translates into a binary privileging of what is deemed Nature, as opposed to the artificial. Since people that hold traditionally heteronormative identities have held the power to define the natural in terms of reproduction, then queer is positioned in binary opposition to heterosexuality. If queer becomes the negative complement of heterosexuality, then "nature" can function as a normative or "anti-liberatory principle promoting the political regulation of human behavior and social practice" (Hutchings 10). However, such violent ideologies are often rendered invisible, or to invoke Rob Nixon, forms of "slow violence" because they are embedded in culture, and often absolved from other hyper-visible forms of violence against queer people, such as conversion therapy, assault, and murder. Morton demonstrates the underpinnings of how heteronormativity diffuses through a Romanticized Nature by arguing that when religious hierarchies invoke a need to do "human ecology the right way" (273) in binary opposition to queer identities, then they are using both natural romanticism and the authoritarianism of their religious ideologies to vilify queer people. In acknowledging the complications between queer identity and environmentalism, a deprivileging of romanticized nature needs to occur in order to create spaces in which queer people have a voice within the environmental justice movement, and feel supported in the midst of increasing climate violence.

Building power to combat a Romanticized Nature dependent on heteronormativity, can prove to be difficult given the extensive historical power figures like Pope Francis have had in establishing an absolute Nature. In order to accomplish a dismantling of heteronormative ideologies, liberatory alternatives, ones that are not grounded on a romanticization of nature or that otherwise show how it can be misused as 
a tool for violence, are necessary. In looking for a radical reimagining of these structures, speculative fiction can hold the capability to construct worlds that challenge heteronormativity. Scholar Stephanie LeMenager states that "Speculative fiction allows a kind of scenario-imagining, not only about the unfolding crisis but also about adaptations and survival strategies", highlighting the importance of speculative fiction in providing solutions to survive the Anthropocene (Pérez-Peña). In agreement with LeMenager, I also argue that speculative fiction is equipped to combat an environmental romanticism that presupposes a nature defined in terms of an inherent heteronormativity. Whereas environmental romanticism assigns, speculative fiction creates possibility for imagining worlds that challenge the status quo. Whereas Christianity and other anthropocentric ideologies, place nature not only as below man, but as a heteronormative entity, the speculative fiction of writers like Octavia Butler reclaim nature as a physical, material structure that is not bound by conventional anthropocentric notions of sexuality and gender. Nature can therefore be imagined in relation to queer, because the ideology that presupposes that these two are separate can be constructed in a space where anthropocentrism is dismantled. Queer people become another facet of difference in the collective materiality of nature, rather than, like much of nature defined as other, as subordinate to heteronormative identities. Butler, therefore, invites the reader to imagine worlds beyond limited oppressive, positivist, and ahistorical structures. To Butler, a changing climate is both fueled and inseparable from legacies of heteronormative white supremacy.

In assessing Butler as a writer that explores both queerness and environmental justice, the academic archive on the works of Octavia Butler provides ample queer and 
ecocritical analysis of her texts. Scholar Amanda Thibodeau, for example, argues that Butler's depiction of aliens in "Bloodchild" presents a breakaway from patriarchal gender performance. Thibodeau argues that "If aliens always already exist outside the normal, and if "queer" means that which is outside or resists regimes of the normal, a queer reading of speculative alien bodies and relationships is a useful and organic approach to analyzing their utopian implications" (265). Similarly, scholar Megan Obourn argues that Butler constructs queer identity in the Xenogenesis trilogy through an alien race known as the Oankali, arguing that " $[\mathrm{T}]$ he Oankali have a queer understanding of gender to the extent that they see it as ideally fluid and individually choice-based, but due to their fear of reproducing illness, they have enacted binary (and racially coded) models that restrict individual" (126-7). However, in spite of critics acknowledging Butler's presentation of queerness through aliens, or other classifications of supernatural beings, few engage in discussing Butler's depiction of embodied, human queerness. In her climate dystopia Parable of the Talents, for example, Butler depicts the human character of Allie as a young queer woman struggling for survival. Therefore, although Butler engages in creating metaphors and parallels to queerness in her texts through aliens and other supernatural beings, her project extends beyond the metaphor of utilizing queerness as a means to depict vastly different futures. In fact, I'd argue that Butler is as concerned with the material, contemporary liberation of queer people as she is with imagining what alternative understandings of gender and sexuality may look like outside of social construction.

In addition to Butler's depiction of embodied human queerness in Parable of the Talents, the Butler archive provides multiple instances in which Butler addresses 
questions of environmental justice. Scholar Frederick Buell, for example, traces a genealogy of contemporary American novels that center the topic of global warming, identifying Butler's Parables as an example of a novel that constructs settings "dealing with crises (crises featuring or prominently including global warming)" (264), which radically alter "the characters' chief way of life" (264). As argued by Buell, Butler's text introduces the imperative of acknowledging global warming. Yet, as argued by scholar Sandra Jackson, Butler's texts did not only acknowledge the existence of global warming, but also engaged in dismantling power structures that produce environmental destruction. Jackson argues that "Butler presents a realistic supplementation to a long-standing religious philosophy that demands the hierarchical empowerment of one group over another (whether that be a human/nature duality or human/subhuman duality)" (21). In assessing Jackson's arguments, as well as that of other scholars that posit Butler as a queer and ecocritical theorist, I conclude that the archival necessity to acknowledge Butler as a writer that speaks to multiple intersecting identities is present. However, what is otherwise currently lacking in the Butler archive is an analysis that explores the intersections of climate justice and queer identity, particularly as it relates to her Parable novels.

Butler, through speculative fiction, imagines a space where queer and nature are interconnected, constructing a world that may otherwise posit heteronormativity invisible. In other words, Butler contributes to the discourse that holds environmental justice movements accountable for ensuring queer liberation. In highlighting the ethical imperative towards dismantling heteronormativity as a system that marginalizes queer people, I posit Butler's Parable of the Talents as a theoretical text that gives visibility to 
the importance of dismantling heteronormative violence. Furthermore, the novel allows for dialogue with queer, feminist, and critical race theory, highlighting Butler's intersectional approach to environmental justice. For example, scholar Jim Miller argues that "Butler is also far more class-conscious than many other utopian femi-nist sciencefiction writers. Thus, her largely dystopian fictions challenge not only patriarchal myths, but also capitalist myths, racist myths, and feminist- utopian myths" (337). Butler's works therefore signify a shift from canonical science fiction, and steps towards centering intersectional an essential aspect of liberation. Therefore, by challenging a predominantly neoliberal genre, Butler echoes the theories of theorists like Audre Lorde, Angela Davis, and José Esteban Muñoz. In constructing Parable of the Talents as a commentator on the intersections of climate change and the violence of heteronormativity, Butler is able to draw together an epistemology that is both queer and ecocritical.

Audre Lorde's theoretical work provides as an accessible tool for understanding the various ideologies that drive heteronormativity and its potential for violence. In her essay "Scratching the Surface: Some Notes on Barriers to Women and Loving", Audre Lorde defines heterosexism as "The belief in the inherent superiority of one pattern of loving and thereby its right to dominance" (45). Whereas heteronormativity manifests itself in active policing of norms and culture based on essentialist ideas of gender and sexuality, heterosexism refers to one of the ideological forms that drive heteronormativity. Drawing from Lorde's understanding of heterosexism, I want to highlight how heterosexism as an ideology can act as a tool of oppression against LGBTQ identities. In particular, I want to make the argument that Parable of the Talents allows the reader to see the various intersections of heterosexist violence that result from 
a desire to impose heteronormativity, demonstrating how religious fundamentalism and ecological catastrophe interact to subjugate queer bodies.

Butler's Parables as Hyper-Visible Representations of Heteronormative Climate Violence In Parable of the Sower, Butler introduces Allie Gilchrist, a young white woman whom the protagonist, Lauren, rescues from a fire along with her sister Jill. The Gilchrists' home was among the many that was targeted by people who abused Pyro, a drug that became popular due to economic uncertainty, scarcity of resources, and a rapidly changing climate. The drug influenced people to burn property, which led to the destruction of various communities, including both Allie's and Lauren's. After Allie joins Lauren's Earthseed community, her struggles are largely confined to surviving the persistent droughts, robberies, and murders that were magnified by both climate change and capitalism. For example, Allie struggles with depression after she loses her sister to an army of thieves that attempted to sabotage Earthseed and rob the community of its resources. After the loss of her sister, Allie is comforted by Lauren and others in her community, and survives the journey to the Pacific Northwest.

Butler, however, did not intend for Parable of the Sower to be a standalone novel. Indeed, although Butler died before she could write the third novel, she intended for the Parable series to be a trilogy. As it was, Butler published the second installment in the series, Parable of the Talents, four years after publishing Parable of the Sower. With Parable of the Talents, Butler's intention was to "consider some of the solutions" to the many problems she explored in the first novel. As such, throughout Parable of the Talents, Butler added layers of nuance and complexity to characters such as Allie, 
examining the specific ways in which the hegemonic politicization of identity shapes how climate violence impacts different peoples disproportionately.

In Parable of the Talents, Allie is reintroduced as a queer woman, adding an important intersection to her identity, and horrifyingly, a degree of oppression which is heightened by the election of an authoritarian leader named Andrew Jarret. Allie is embraced by Earthseed, but left vulnerable to rising religious fundamentalism. As argued by scholar Philip H. Jos, "the Parable books two dramatically different responses to fear: The Christian America movement, which exploits it and marries religious dogmatism to political authority, and Earthseed, and alternative faith that seeks to respond creatively, productively, and humanely to overwhelming fear (409)." In the context of Jos' argument, Earthseed becomes a refuge for the marginalized, whereas Jarret's America becomes a crusader against identities that do not fit the Christian foundation of the United States. In advocating for theocracy, Jarret promises to restore America to a moral time. Specifically, Jarret promises to save the country from the people that have destroyed it, including queer people, who do not fit a heteronormative Christian ideal. As a result, Allie must now not only survive the scarcities of climate change, but the heteronormative violence directed at her due to her queer identity. Using Allie as an example, Octavia Butler demonstrates the vulnerabilities that queer people experience due to environmental injustice.

Many of Jarret's supporters feel emboldened by his promise to make America a God-fearing and law abiding nation. Lauren emphasizes their intentions to materialize their vision of America, stating that “They will strip us. They've made that all too clear. They will break us down, reshape us, teach us what it means to love their country and 
fear their God" (184). Lauren's ideal America radically differs from Jarret's, as the foundation of Lauren's Earthseed philosophy and community are grounded in embracing difference. Earthseed therefore exemplifies what Audre Lorde argues in her essay "The Master's Tools will not Dismantle the Master's House," which is that "community must not mean a shedding of our differences, nor the pathetic pretense that these differences do not exist" (112). The similarities between Octavia Butler's and Audre Lorde's vision of community has been emphasized by scholars such as Patricia Melzer, who argue that the novel's depiction of "[C]hange and its implications inject a transformative element into the conceptualizations of difference that enables not only a new perception of difference, such as Audre Lorde calls for in Sister Outsider, but that demands a constant redefinition of its categories. It is especially in this respect that Butler's Utopian desire contributes to the feminist discourse" (36). Lorde's understanding of community is so cementented in the philosophy of Earthseed that is presented by Lauren as commandment, as she states in Parable of the Sower:

Embrace diversity.

Unite-

Or be divided, robbed, ruled, killed

By those who see you as prey. Embrace diversity Or be destroyed (196) 
Because Eartherseed emblematizes founding ideals that intentionally and radically differ from a homogenous, white supremacist state, her community becomes the target of NeoNazi groups. These Neo-Nazis are emboldened by president-elect Jarrett, whose rhetoric allows for his supporters to "hear what they want to hear" (19). They feel validated by a rhetoric that calls for America to return to a past where the white, heteronormative family unit is preserved against both environmental and societal forces that are attempting to destroy its foundations. Consequently, these supporters feel entitled to "protect" the homogeneities of the white supremacist, heteronormative state by behaving violently against communities like Earthseed.

In constructing both Jarret and his fellowship of Neo-Nazis, Butler demonstrates a hyper-awareness of the political climate of the upcoming millennium. Describing his findings among the Butler papers at the Huntington Library, Scholar Gerry Canavan, documents how Butler constructed Jarret to resemble Ronald Reagan. Canavan describes Butler's distaste for Reagan as follows:

The Parables' President Jarrett—a figure she refers to in her notes as "President Hitler"- is in fact described in her notes as "a Reagan, young, vigorous, and utterly unencumbered by conscience." Another personal notebook containing sketches of "the basic character types" includes Reagan alongside the "intelligent monster" (Trump lawyer and mentor Roy Cohn) and "the semi-intelligent monster/betrayer" (Clarence Thomas); the Reagan archetype is "amoral, ambitious [....] Would sell his mother but then convince people she wanted to be sold. 
In understanding the people who would willingly support an amoral Reagan, or within the context of the novel, a Jarret, the Neo-Nazis of Parable of the Talents embody a material, contemporary relevance. These Neo-Nazis share close resemblance to the contemporary Christian right, as well as the so-called "alt-right.” Scholar Linda Kintz argues that conservative Christians used ideologies of restoration, or returning to a moral America, in order to vilify homosexuality. For example, Kintz mentions how the Oregon Citizens Alliance, a religious fundamentalist organization, would push to ban homosexuality on the basis that it was "abnormal, wrong, unnatural, and perverse" (95), forming coalitions with other far-right groups in the process. Within a contemporary context, Butler's Neo-Nazis also speak to the alt-right movement, or to put in more succinct terms, masqueraded white supremacy. In an article written by Joseph Goldstein for The New York Times, Goldstein refers to one of the alt-right's leaders, Richard B. Spencer, as a normalizer of white supremacy:

But now [Spencer's] tone changed as he began to tell the audience of more than 200 people, mostly young men, what they had been waiting to hear. He railed against Jews and, with a smile, quoted Nazi propaganda in the original German. America, he said, belonged to white people, whom he called the "children of the sun," a race of conquerors and creators who had been marginalized but now, in the era of President-elect Donald J. Trump, were "awakening to their own identity".

I find that both the alt-right movement and Christian right help contextualize the ideologies of Jarret. In representing these ideologies within Parable of the Talents, Butler demonstrates that she is simultaneously hyper-aware of how oppression operates and is 
disseminated in the present, and capable of predicting how these systems, if unchecked, can further unfold into the dehumanization of others. Scholars, such as Peter G. Stillman, have pointed to Butler's ability to depict the dissemination of oppressive systems, stating that "Butler's dystopian images or maps serve as a warning to the present because she ties her images to existing problems and ideologies. Each Parable text evinces Butler's feel, insight, and prescience about American politics" (15). Butler's depiction of authoritarian leaders such as Jarret, as well as their followers, not only demonstrates knowledge of contemporary American politics, but highlights Butler's ability to foresee the tactics of the alt-right and the Christian-right within a futuristic America. Jarret and his followers often hold Christian, heteronormative, and white identities, and use these identifiers as a means to justify the persecution of others that do not fit these rigid identities. To them, America has always been theirs to define. Many of these people, due to a denial of difference, chose to blame others who do not fit these identities for climate destruction and other forms of economic despair, rather than look at how systemic capitalism is predominantly responsible for the scarcities that come with a changing climate.

Difference itself, such as queerness, becomes the cause of catastrophe, as it defies how essential, natural America is supposed to function.

As a result, Jarret supporters decide to take justice into their hands, and direct violence at people like Allie. These invaders, whom Lauren would later call maggots, invaded the Earthseed community and began to terrorize people into accepting their ideologies. The "maggots" did not necessarily come with the intention to kill, but to indoctrinate. In the process of "firing gas canisters" (187) at Lauren and her people, however, the maggots did end up killing several members of the community. The people 
who survived were locked within different areas of Earthseed grounds, a process which was reminiscent of Nazi Germany and the internment of Japanese Americans in the United States. In wanting to restore order, i.e; heteronormativity, to America, the maggots began to separate the imprisoned Earthseed community by gender, emphasizing a biological essentialism that differentiates men and women, and proclaiming that men and women should only congregate for purposes of procreation. Lauren describes these ideologies in detail when she explains that the maggots told the community, "it's time for you to learn to behave like decent Christian women -- if you've got the brains to learn" (203), which was followed by Lauren's suggestion that, to the maggots, "We were a dirty cult of free lovers, and they had to straighten us out. Educate us" (203). To the maggots, any deviation from heteronormativity embodied the cult of free love, and needed to be annihilated, or in other words, receive conversion therapy.

I argue that the practice of conversion therapy did not only influence, but was central in how Butler saw the violence of heteronormativity be imposed against queer people. In an interview with writers Larry McCafferty and Jim McMenamin, Octavia Butler discusses her experiences with homophobia, and interests in exploring queer identity in her work and imagination. Butler states:

Because of the way I looked, when I was growing up, I was called various and unsavory names by people who thought I was gay (though at the time nobody used that word). I eventually wondered if they might not right, so I called the Gay and Lesbian Services Center and asked if they had meetings where people could talk about such things. I wound up going down there twice, at which point I realized, Nope, this ain't it...At any 
rate, I was intrigued by gay sexuality, enough so that I wanted to play around with it in my imagination and in my work...(58)

Conversion therapy, according to numerous scholars such as Valerie Canady, is defined as "efforts to change an individual's sexual orientation, gender identity, or gender expression." The practice has been found to be harmful towards LGBTQ people who are forced to undergo the process. Butler constructs a world where in order for America as nation to return to its roots, converting anomalies back to a romanticized heteronormative model is imperative. In Butler's dystopian vision of a future United States, there are numerous Christian camps that force people to "be a servant of God and God's true church and loyal citizen of the greatest country in the world" (230). Earthseed has been colonized, and is now a Christian camp with a set of rules meant to punish people like Allie, who commit the sin of a loving that reimagines the heteronormative model.

As the Earthseed community is separated on the basis of gender, Allie begins to find comfort, love, and support with another woman in her group, named Mary Sullivan. Lauren describes their love for one another, when she states "Mary Sullivan and Allie combine their blankets and make love to one another late at night. It comforts them" (223). When Mary asks Lauren if she disapproves of her relationship with Allie, Lauren responds by asking, "Do you love my friend” (223), to which Mary replies, "Of course I do!" (224). Invoking the values established at Earthseed, which embrace difference as opposed to repress it under a misguided sense of holding absolute truth, Lauren replies that "if there's any trouble, you and your sisters stand with us, with Earthseed" (224). In highlighting these different approaches to understanding, embracing, and standing in solidarity with LGBTQ people, Butler's narrative provides an antidote to the violent, 
heteronormative model that comes from validating a romanticized American past. The solutions presented in the novel speak to other theoretical frameworks that advocate for difference, such as Lorde's and Davis's texts. Butler's novel, by embracing coalitions of resistance, acts as a praxis towards dismantling heteronormative violence.

After the comforting interaction between Lauren and Mary, Butler proceeds to depict how, in a heteronormative world, queer lives are imperiled. The newly established camp Christian is increasingly intolerant of Earthseed and its unwillingness to assimilate. Allie, being a queer woman, is left vulnerable to the attacks of the Christians, who feel threatened by Allie's homosexuality. After Allie is outed, Lauren states that "Allie...Allie might die. Or she may be permanently brain damaged" (246). Acknowledging the uncertainty of Allie's fate, Lauren states that such hyper-visible examples of violence against people like Allie compel her to decide that Earthseed has to "risk a breakout soon" from the theocratic regime that are the Christian camps (246). Allie and Mary's relationship is outed by people from within Earthseed community, two women who prioritized better relationships with their oppressors, in exchange for the lives of Allie and Mary. One of the women, Beth, said that "you can hear them kissing and making noises" (250), which she followed by an exclamation of disgust, shouting "Perverted!" (250). Following Beth's attack, another woman named Jessica exclaims that "I thought she was okay because she had a little boy, but now I know she wasn't" (250). Jessica's statement represents another facet of the violence of heteronormativity that defines children in terms of the heterosexual relation. Allie being single and with a child at least kept open the possibility of heterosexual fulfillment, but to people like Beth, that possibility is foreclosed and defined as grotesque when she realizes that Allie is forming 
bonds with another woman. To Camp Christian, queer families are not valid because they do not fit the model of compulsory, procreational heterosexuality.

After the continuous attacks by other women within Earthseed towards Allie and Mary, Beth states that Mary Sullivan was "strong like a man, and she's mean" (250). Because Sullivan does not fit heteronormative notions of femininity, Beth implores the guards at Camp Christian to punish her. In her book Undoing Gender, theorist Judith Butler highlights how performing gender and sexuality in a manner that challenges heteronormativity often leads to material violence. Judith Butler states;

When gender norms operate as violations, they function as an interpellation that one refuses only by agreeing to pay the consequences: losing one's job, home, the prospects for desire, or for life.... The consequences can be severe. It won't do to call this merely play or fun, even if those constitute significant moments. I don't mean to say that gender is not sometimes play, pleasure, fun, and fantasy; it surely is. I only mean to say that we continue to live in a world in which one can risk serious disenfranchisement and physical violence for the pleasure one seeks, the fantasy one embodies, the gender one performs (214).

Octavia Butler compliments Judith Butler's analysis by adding a layer of gruesome, traumatic violence that is directed towards both Allie and Mary. As punishment for sodomy, the maggots "lashed both women until neither could scream anymore" (251). Mary is described as experiencing "terrible convulsions," but to the maggots repentance meant continuous torture until either women showed signs of remorse, or a conviction 
towards Christianity. After the lashings, Lauren describes the horrific consequences: "they lashed Allie and Mary until Mary died. They lashed them until Allie was lost somewhere within herself. She hasn't spoken a full sentence since the lashing" (251). In demonstrating these vile acts of violence, Octavia Butler highlights that an essentialist heteronormativity validated by the imposition of theocracy cannot be innocent, especially when material queer lives are brutalized as a result. Octavia Butler highlights the most hyper-visible forms of violence against queer people, which directly invoke physical pain. However, as Octavia Butler demonstrates, the trauma that queer people experience often constitutes continuous disenfranchisement and danger that extends to more invisible forms of slow violence, for example, being continuously fearful for one's life, and the health effects that trauma deposits on our well-being. Allie can never again be the Allie she was before she was exposed to the violence of heteronormativity, even if heterosexism were to be theoretically dismantled or diminished. Octavia Butler and Judith Butler both highlight that the scars that come with the violence of heteronormativity are material effects, unable to ever fully heal over time, and that an acknowledgment of responsibility needs to occur. In our models of social and environmental justice, the liberation of queer people must not be a matter of theory, but one of praxis, or as black feminist theorist Angela Davis would say, "a constant struggle".

Parable of the Talents helps us to see that incorporating queer liberation is an imperative of environmental justice, although one that many activists and theorists do not fully incorporate it into their work. In the beginning of Parable of the Talents, Butler highlights that the issues that will be explored later in the novel, such as 
heteronormativity, are very much fueled by climate violence. When Lauren, for example, states that "I have watched as convenience, profit, and inertia excused greater and more environmental degradation" (8), Lauren highlights that forms of environmental injustice have increased from the time she was born in the 2000's. Lauren emphasizes that the Pox, which is the term Lauren uses to describe the apocalyptic collapse of America whose immediate aftereffects are seen in Parable of the Sower, coincided with "climatic, economic, and sociological causes" (8). In other words, the theocratic apocalypse of Parable of the Talents is inseparable from climate change as an instigator for violence against others. Octavia Butler herself reminds us of the connection between increased authoritarianism and climate violence in an interview with internet news program Democracy Now!, in which she states, I wrote the two Parable books back in the 1990s. And they are books about, as I said, what happens because we don't trouble to correct some of the problems that we're brewing for ourselves right now. Global warming is one of those problems. And I was aware of it back in the 1980s. I was reading books about it. And a lot of people were seeing it as politics, as something very iffy, as something they could ignore because nothing was going to come of it tomorrow.

According to the interview, Butler wrote the Parables at a time where the legitimacy of issues like climate change were often questioned. Similarly, I make the case that a Romanticized Nature, due to its cultural invisibility, is privileged as truth. These romanticized models of nature often impose a heteronormative paradigm of the world, which are inextricable from a Christian creationism that partakes in enforcing a romantic 
binarism that institute women and men as codependent on one another. An example of a romanticized United States that existed before climate change is explained by Lauren, who explains that Jarret "wants to take us all back to some magical time when everyone believed in the same God, worshipped him in the same way, and understood that their safety in the universe depended on completing the same religious rituals and stomping anyone who was different" (19). As demonstrated throughout Butler's novel, Christianity did not shield the world from the catastrophes of climate change, yet rather than question the foundations of Christianity's capacity to provide sustainable ways of living, the people attribute environmental catastrophe to difference. By difference, as demonstrated by the persecution of queer people throughout the novel, Butler means people that perform in ways that fall outside of the Christian paradigm of righteousness, or otherwise known as what the Catholic hierarchy would define as proper nature.

Yet, Butler also gives agency to Allie, by both acknowledging her trauma but allowing her to not be defined by her experiences. After recognizing the imperative to escape the violent heteronormativity of camp Christian, Earthseed, as a collective, burn down camp Christian after nearly two years of imprisonment. Lauren describes the burning as horrifying, but materially necessary, stating that they burned "our keepers as we went" (266). Even after attaining the possibility of liberation, however, Allie is still affected both by her dehumanization and the killing of her lover. As Lauren describes the trauma Allie is experiencing, "Only Allie awoke alone, huddled in fetal position in her blanket. I had forgotten her. And hadn't she lost even more than the rest of us?" (270). That moment recognizes that although the entire Earthseed community felt a universal suffering, Allie being a queer woman left her vulnerable to the violence of 
heteronormativity. As part of the healing process, Lauren and Allie share a tender scene in which Lauren combs Allie's hair, stating that "things like that had begun to matter again, somehow" (270). Allie, as part of her recovery, finds herself unable to speak. Yet, in Lauren combing Allie's hair, Butler reminds us that care and accounting for an other's needs is not verbally restricted. The reconstruction of community can begin again, and in the new Earthseed, Allie's liberation as a queer woman becomes as imperative as Lauren's - a matter of collective liberation.

Beyond trauma, however, Allie has numerous ruptures of happiness throughout the novel that give a vivid nuance to her character. For example, she is able to reunite with her son Justin, who along with the other children of Earthseed, were taken away for the purposes of Christian indoctrination. Yet, rather than simply adding another instance of heteronormative violence thrown Allie that would have continue to perpetuate her character as bound by trauma, Justin responds with concern for his mother's safety. Lauren describes their reunion as highly emotive, adding that she "watched them meet, saw Allie's joyful tears, heard her cries" (287). Justin could have easily grown up to hate his mother given the extensive amount of torture non-Christians had to go through to be indoctrinated by Camp Christian, including being subjected to electroshock therapy through collars around their necks. Yet, Lauren emphasizes, "Justin had not turned against Allie, no matter what he had been told about her" (290). To Justin, the recollections of a brave, compassionate woman that took him as an abandoned refugee of the Pox, were much stronger than the perverse heteronormativity that Camp Christian attempted to force upon him. Allie is allowed to rest, and before coming back to reunite with Lauren as part of the Earthseed community, she is able to live and cherish the life of 
her son. Butler reminds the reader that there is power in these successes, even if heteronormativity is still prevalent. Lauren writes, "Justin is with us again! He's alright. There is hope. God is change" (295). Building communities that dismantle heteronormativity may prove to be difficult, but the possibility, rather than the enclosure of struggle, creates the potential for a material freedom.

Towards the end of the novel, Allie does not necessarily take an activist role. Lauren describes Allie as living happily to the best of her capacities, stating that she “didn't teach writing or writing as I had. She claimed she did not have the patience for that kind of teaching -- although she was willing to show kids how to work with wood, and she fixed their broken toys for free...Allie was allowed to do the things she loved for her living and for Justin's" (333). In accounting for difference, a queer person should not have to defend their identity in order for their existence to be valid and survive the violence of a heteronormative world. Accounting for and respecting Allie's happiness, Lauren goes off on a journey to spread the values of Earthseed, ones which prioritize community and a decentralized interconnectivity with nature. In speaking to a woman about the movement, Lauren states that "Earthseed is about preparing to fulfill the Destiny. It's about learning to live in partnership with one another in small communities, and at the same time, working out a sustainable partnership with our environment" (3589). Once Lauren's movement grows across the United States, Lauren invites both Lauren and Allie to live with her in a community in Oregon. To live in an Earthseed community becomes a matter of recognizing living in relation to one another and the environment, and a not a mere testament of one's ability to establish oneself as a whole human being. Allie's dream, to fight for the survival of her son in the midst of a violent, 
heteronormative world becomes materialized. By the epilogue of the novel, decades later after the election of Jarret and the imposition of Christian America, Justin Gilchrist is described as an astronaut to an extraterrestrial mission, “even though he shouldn't have been at his age" (405). Just as the values of Christian America remain relics of the past, including the violent heteronormativity of Christian America, the individual dreams of Allie are also materialized. Allie is given the opportunity to see her son succeed, in a world that actively tells queer parents that their communities do not matter.

Rather than look towards a past before climate change for solutions, I argue that the movement towards environmental justice, which includes queer liberation, needs to move forward by matter of necessity. By this I mean that relying on ideologies that reduce both nature and queer to an other, rather than as interconnected experiences that can flourish towards reimagining worlds not bound by environmental degradation is imperative. In doing so, I want to emphasize the words of theorists such as José Esteban Muñoz, who has said that "Queerness is not yet here. Queerness is an ideality. Put another way, we are not yet queer... Queerness is also a performative because it is not simply a being but a doing for and toward the future. Queerness is essentially about the rejection of a here and now and an insistence on potentiality or concrete possibility for another world" (1). We must not look back towards simpler ways of existing or ideologies that once made America great, because such greatness is unextractable from patriarchy, homophobia, and transphobia, as well as the destruction of the land.

With increasing support for Christian, white Nationalist, and other ideologies that erase as opposed to celebrating our differences in accounting for the liberation of one another, Butler demonstrates the violence of individualist notions of salvation. In the case 
of Parable of the Talents, Jarret believers burn, and often kill, people like Allie, with the hopes of restoring the kingdom of God on Earth. Such material forms of violence are carried out against Allie, whose forced rehabilitation often entailed being left without eating and physical abuse. Butler therefore provides a reminder that climate justice movements need to engage difference to be just and liberatory towards all. As argued by scholar Clauda Escoda Agusti, "difference needs to be continually acknowledged and renegotiated" (358). Agusti analysis speaks to the words of Angela Davis in her book Freedom is a Constant Struggle, in which Davis states that "if the intersectionality of struggles against racism, homophobia, and transphobia is minimized, we will never achieve significant victories in our fight for justice" (89). Both Davis and Agusti encourage people to constantly redefining approaches to social justice that are not dependent on the past, but account for the ways in which beings are constantly changing. In adopting an environmental justice praxis that resists stagnation, and examines ways in which movements can continue to be more inclusive of difference, then an arrival towards justice can materialize.

\section{Section 2: Decolonizing Feminisms: Lorde, Mock, Morrison, and}

\section{Reimagining Womanhood}

Increasing emphasis on the experiences of transgender, gender non-conforming, and intersex peoples has led to increasing discourse on what gender constitutes. In particular, womanhood as such, which for a large portion of history has been tied to a biological reality that is assumed to be unique to women, is being revalued as a social construct. Germinal queer and feminist theorists, such as Judith Butler, gives validity to 
the argument that gender is a construct, stating that "[W]hen the constructed status of gender is theorized as radically independent of sex, gender itself becomes a free-floating artifice, with the consequence that man and masculine might just as easily signify a female body" (10). In thinking about who has had the power to define, regulate, and impose womanhood, I argue that both Toni Morrison and Audre Lorde challenge us to revalue womanhood as a singular, homogenous identity that privileges white upper and middle class cis women as subjects.

At the time Toni Morrison wrote Beloved in 1987, novels that accounted for the experiences of black women were virtually unrecognized by the literary canon. The erasure of black women and their narratives is demonstrated by the fact that Morrison is the only black women to have ever won the Nobel prize in Literature, an accomplishment which is often undermined in the U.S public education system, as numerous schools either do not acknowledge Morrison's work, or dismiss it as not appropriate for the classroom. Morrison herself speaks of the censorship she is subjected to as a black woman, stating that "You bounce back and forth from control or instructions about what you cannot read, into, as I did, a family that was certain that this was the route out of any oppression, any limitation, that happened. That reading was not just pleasure, it was knowing if you can read they can teach you" (Morrison). In contrast, white women writers like Virginia Woolf, have an extensive history of receiving more validation, in spite of the shared oppression that both white and black women face under patriarchy. The validation a writer such as Woolf receives, however well accomplished, highlights a disparity as to which narratives are privileged in defining the experiences of women. Alice Walker, for example, speaks to the danger in the assumption that Woolf could 
potentially speak to all women. In a 1974 essay titled "In Search of Our Mothers' Gardens", Walker states "What then are we to make of Phillis Wheatley, a slave, who owned not even herself' (93), in response to Woolf proclaiming that all a woman needs to write is money and a room of one's own. The position of black women therefore radically differs from that of white women, in that they are not only considered subjects to men, but that for centuries of material history they were also not considered freewilling persons capable of constructing self, or in other words, identity. The article "The Cult of True Womanhood" by Barbara Welter precisely demonstrates what was required for a woman to establish womanhood, arguing that according to society "The true woman's place was unquestionably her own fireside - as daughter, sister, but most of all as wife and mother, Therefore domesticity was among the virtues most prized by women's magazines" (5). Black women, who were denied access to have domestic spaces in which they were not separated by their families, however oppressive and limiting of any woman these domestic spaces may have been, did not have access to woman as identity, or at least woman in terms of white supremacist patriarchy.

Hazel Carby highlights a history of black women being excluded from woman as identity in her book Reconstructing Womanhood: The Emergence of the Afro-Ameircan Woman Novalist, pointing to how white culture constructed black womanhood as lacking in proper "womaness". Carby argues that in the absence of a woman identity defined in terms of whiteness, "stereotypes about the black woman" (20) grounded in slavery masqueraded themselves as inherently valid. As a result, white women were often placed in binary opposition to black women, because a lot of the stereotypes that related to black womanhood did not fit proper femininity. According to Carby, "strength and ability to 
bear fatigue" (25) were argued to be in opposition to how a white woman should behave. In contrast, black women were often forced into conditions in which they needed to perform hard manual labor. Black women were dehumanized not only in terms of abuse, but in being stripped of the ability to define themselves and their own womanhood. Bell hooks further expands on how black women's lack of recognized identity lead to them being treated the same, if not worst than black men. In her book Ain't I a Woman, Hooks states that "on any plantation with substantial number of female slaves, black women performed the same tasks as black men; they plowed, planted, and harvested crops. On some plantations black women worked longer hours in the field than black men" (23). Yet, in spite of black women being treated the same as black men for the purposes of producing capital, the material, violent realities of being a woman still affected black women, even if their identities were not constructed the same as white women. In doing so, hooks highlights that in spite of both black men and women being stripped of a gender identity and reduced to objects, "the black female was exploited as a laborer in the fields, a worker in the domestic household, and as an object of white male sexual assault" (22). Yet under monolithic understandings of slavery that do not account for difference, the experiences of black women are forgotten. What novels like Toni Morrison's Beloved do are therefore of moral imperative, in order to ensure that black women experiences are not erased.

In Beloved, Morrison not only depicts black women that reclaim identity and establish their womanhood, but given how woman as constructed by white supremacy was only accessible to white women, demonstrates how characters like Sethe reimagine a womanhood that is not dependent on white supremacist patriarchy. In writing characters 
that reclaim womanhood and identity, Morrison engages in highlighting that there is not a singular experience to "womanness", and that womaness itself can be reconstructed and challenged from its white supremacist and patriarchal roots.

Morrison introduces Sethe, as a black woman who has escaped slavery, and is currently living as a free woman in Cincinnati. In spite of her apparent liberation, however, Sethe carries the scars of living within a white supremacist system. For one, the ghost of her dead daughter Beloved, who Sethe killed to avoid sending her into enslavement, haunts her. The novel establishes the trauma losing Beloved has on Sethe, establishing Sethe's 124 home as "spiteful" and "full of baby's venom". In addition to the struggles that arise from having to kill one's own daughter, Sethe also has to confront not knowing her mother. Morrison highlights Sethe's forced detachment from her mother, stating "Of that place where she was born ... she remembered only songs and dance. Not even her own mother, who was pointed out to her by the eight-year-old child who watched over the young ones- pointed out as the one among many backs turned away from her, stooping in a watery field" (30). Sethe is deprived of the privilege to experience two, seemingly essential, aspects of womanhood - the ability of raising children of one's own, and the socialization of womaness that is attributed to be acquired from our mothers. That is not to say there are no ruptures within Beloved in which Sethe has access to these experiences associated with womanhood, as demonstrated by the fact that Sethe still has her daughter Denver, and that Baby Suggs, her grandmother, acts as mother figure to Sethe in the absence of her nameless mother. Rather, Sethe has to deal with the violence of being prescribed as not woman, or rather someone who is not a whole woman because white supremacy is complicit in being capable of taking her 
children at any time, as well as the family structure which allows for the passing of womanhood from mothers to daughters.

As a result of Sethe being othered and not having access to aligning herself with white womanhood, Sethe is continuously troubled by experiences that are unique to her as a black woman. For example, under patriarchal society both black and white women face overwhelmingly high possibilities of being raped. However, when Sethe is raped (Morrison 86), she faces the trauma of having to live in a world that simultaneously devalues her on the basis of race and gender. Meaning that for Sethe, to bring a childlike Beloved into the world, she must reconcile that her value as non-human, both by virtue of gender and race, would leave her child vulnerable to the abuses of white men. If Sethe cannot engage in womanhood, as in womanhood that constructs women in terms of their domestic and reproductive capabilities, then Sethe by both gender and race is othered as less than woman. Another instance when Sethe struggles with being denied access to womanhood is when she talks about marrying Halle to Mrs Garner. Sethe asks Mrs Garner "Is there a wedding?" (36) in relation to her marriage to Halle, to which Mrs Garner responds by laughing and replying to her "You are one sweet child" (36). The following scene demonstrates how Sethe struggles with being unable to attain woman as identity, as she envisions a wedding in a world that black women do not belong as either brides or grooms, but property.

Yet in spite of any attempts to dehumanize her as a woman, Sethe's connection to Beloved and mourning over her loss are affirmations of a tenderness that was often denied between enslaved black women and their children. Sethe, in communication with Beloved, states "Do you forgive me? Will you stay? You safe here now" (Morrison 121). 
Sethe's unwillingness to heal from the death of her daughter Beloved, although brought to fruition by the horrors of white supremacy, challenges the notion that maternity, acts as an essential exclusive that belongs to white women. Sether's mourning then, however indirectly, becomes a way to reclaim a womanhood that has been actively denied to her. Sethe's relationship with Beloved, defies the notion that maternal relations can only be experienced in terms of domesticity, as in the process of raising children. They persist even in death, which is an experience that black enslaved women often faced when their children fell victim at the hands of white supremacy. Theorists, such as O'mesake Natasha Tinsley, touch upon non-traditional ways of relation among the enslaved who had to survive the pervasive effects of white supremacy. Tinsley states, "Queer in the sense of making disruption to the violence of normative order and powerfully so: connecting in ways that commodified flesh was never supposed to, loving your own kind when your kind was supposed to cease to exist, forging interpersonal connections that counteract imperial desires for African's deaths" (21). Sethe's love for Beloved remains, even if Beloved herself has ceased to exist and can no longer physically be there with her mother.

Yet in maintaining her relationship with Beloved, Sethe's reclamation of her selfhood must not be codependent upon her relationship with her daughter. In acknowledging the past, and not allowing white supremacy the power to keep haunting her, Sethe and Halle come to the conclusion that "We need some kind of tomorrow" (155). Beloved is still very much a part of the experiences of Sethe, but Sethe is ready to not let grievances disrupt her happiness with Halle. In doing so, Sethe reconstructs the womanhood that has been denied to her as a slave. She allows herself to be loved a 
person, and the decision to kill her child does not make her any less of a woman, in spite of how hard white supremacy attempted to strip her of everything she loved.

Morrison demonstrates how womanhood, in spite of it theoretically being a social construction, is imperative to claim for the many people who for centuries, have had their humanity and sense of identity invalidated. Given how white supremacist patriarchy operates to create hierarchies that prevent the other from living autonomously, I want to emphasize a tradition of black women writers who have actively challenged white supremacist patriarchy through the reconstruction of identity in the face of what Audre Lorde would refer to, as the white supremacist dragon that is America. Some of these black women writers include Morrison herself, along with Audre Lorde, Octavia Butler, and Alice Walker. Most recently, black trans women like Janet Mock are making their voices heard, and are among the many black women who are doing the work of reimagining identity beyond the limitations of white supremacist patriarchy. A thread which unites these writers is that they do not erase difference, specifically race, when writing about their experiences. Rather, they challenged a feminism that is grounded in white supremacy and constitutes white women as subject, and all other women as other.

Drawing from Morrison, I want to further extend the ethical imperative towards acknowledging a multiplicity of womanhood, the possibility to reconstruct oneself in a world that tells transgender people, for example, that their identities are invalid. In doing so, I want to caution that by no means can oppression based on gender and race be equated when talking about the ways white supremacist patriarchy limits others from establishing identity, but rather that Morrison provides a framework to establish how denial of the other, is in itself a form of violence that can manifest itself in various ways, 
depending on the privileges one carries. In recognizing how transgender people, particularly black transgender women, have been excluded in other ways by a feminism that claims to represent all women, I will argue that transgender identity and feminism support and build upon one another. In advocating for transgender inclusion, I will highlight in specific how Lorde's embracing of difference does not only speak to the work of writers like Morrison, but that her work can also empower, and provide nourishment to transgender women who too are often not allowed to establish their womanhood.

A theoretical emphasis on materiality, which is constant throughout Beloved and Morrison's depiction of how white supremacy is given the power to define womanhood, can be found in Audre Lorde's essay, “The Master's Tools Will Never Dismantle the Master's House*," which is part of a collection of essays found within a collection of her essays entitled Sister Outsider. Lorde's critique of feminist discourse, grounded on the concrete materiality of being a black lesbian living in the United States during the 1970's, is evident throughout all her essays. In it, she writes as though reclaiming materiality within academic feminist spaces; spaces which have largely theorized the experiences of women deemed as other. Lorde inquires, "What does it mean when the tools of a racist patriarchy are used to examine the fruits of that same patriarchy?" (Sister Outsider 111). Drawing from Lorde's inquiry, I question a similar problematic, asking, "What does it mean when the tools of transmisogynist patriarchy are used to examine the fruits of that patriarchy?"

In attempting to answer these questions regarding the material realities that trans people face for having identities that are constructed as not filling an essential, biological 
"maleness or womaness", I point to the prison-industrial complex. Trans people that are unable fit heteronormative beauty standards when expressing their identities are routinely subjected to discrimination, assault, and murder, even more so in the prison system. In an essay found within the book Captive Genders, titled "Being and Incarcerated Transperson: Shouldn't People Care," Clifton Gorling and Candi Raine Sweet give personal accounts of this violence through their perspective as trans people that have experienced living within the prison-industrial complex. They state, "I have been homeless and I am still currently poor. While in prison, I have been cut by other prisoners for refusing to perform sexual acts for them, and I have been beaten and sexually assaulted (sodomized with the nightstick) by correctional staff. I see first-hand the very issues that the system needs to change" (Gorling and Sweet 185). The personal accounts that both Gorling and Sweet provide hones in on the imperative to mitigate violence against trans folk, which range from the denial of jobs due to perceived misalignment between constructed gender and sex, to being subjected to sexual assault within the prison-industrial complex that leaves trans women vulnerable to assault by cis men because they are sexed as males. I draw attention to these examples to later demonstrate how Lorde's praxis of a feminism that supports difference, is crucial in highlighting why feminism needs to be ethically responsible in not dismissing the experiences of trans women.

On May 6, 1979, Audre Lorde wrote a letter to prominent radical feminist scholar Mary Daly. In the letter, Lorde addresses Daly's book Gyn/Ecology, stating that although the book is critical of patriarchal domination, it fails to account for the experiences of women of color (Sister Outsider 66-71). Largely absent from Lorde's critique, however, 
is the fact that Daly's book is alarmingly dismissive of transgender women. In fact, Daly goes as far as to characterize transgender identities as an example of patriarchal supremacy, stating that "Today the Frankenstein phenomenon is omnipresent ... in ... phallocratic technology.... Transsexualism is an example of male surgical siring which invades the female world with substitutes" (70-71). Lorde's choice to not comment on Daly's views on transgender people, although potentially political, does not reduce the validity of her letter. In fact, I'd argue that Lorde's focus on the omission of women of color is a necessary response to colorblind feminism. Furthermore, I argue that in spite of Lorde not mentioning transgender people in her works, her critique of white feminism is already undoing the politics of exclusionary white women, which attempt to assimilate to the patriarchal structure, and dismiss the marginalization of women of color who they deem as other. My intent is therefore to not dismiss Lorde's response, but rather, to build on Lorde's critique of Daly. Lorde decentralizes white women as the subject of womanhood, and paves the way to dismantle a white supremacist feminism which excludes, rather than celebrates differences.

Throughout her memoir, Janet Mock expresses that she holds admiration towards various black women who have helped her establish her identity as a woman. Among these women is Audre Lorde, who Mock praises for her dedication to thrive in the midst of a patriarchal system. In particular, Mock references Lorde's emphasis on selfdefinition and survival, stating that "Self-definition and self-determination is about the many varied decisions that we make to compose and journey toward ourselves, about the audacity and strength to proclaim, create, and evolve into who we know ourselves be" (2). Part of the journey Mock describes is the freedom to radically redefine notions of 
masculinity, femininity, and non-binary identities, and establish our identities as not bound by biological sex. However, as a result of challenging essentialist notions of gender, according to prominent theorists such as Julia Serano, trans women experience heightened amount of violence, assault, and life-threatening conditions. In acknowledging the terrifying prospects trans women face, writers like Lorde can bring much needed solace and immediate validation. For example, Lorde gives spiritual guidance when dealing with oppression in the book The Cancer Journals, stating that "When I dare to be powerful, to use my strength in the service of my vision, then it becomes less and less important whether I am afraid" (13). Lorde's language encourages trans women to break free from the silences that often prevents them from living their authentic selves. As demonstrated in her essay "The Transformation of Silence into Action", Lorde makes the case for living boldly, in spite of existing within a white supremacist, heterosexist, and patriarchal culture. Lorde tells her audience, "Your silences will not protect you" from the violence of a world that disregards difference. For trans women, some who experience dysphoria and hurt over not being able to express their identities, yet fear living the consequences of challenging gender norms, Lorde's statement could not resonate more. One can't ignore the material realities and forms of oppression, as wells as layers of privilege that may determine whether a trans person choses to out themselves.

Given how intrinsic systems of oppression, such as a white supremacy and patriarchy are to the foundation of U.S society, finding avenues to break silences, in spite of our capacity to be aware of our mortality, can be emotionally taxing. Coming to terms with our truths often requires acknowledgement of positionality in relation to these 
systems, and for marginalized peoples that often comes with revisiting traumatic experiences. I argue that poetry can be a form of self-reflection that allows the writer a space to break from the silences, in a manner that is both highly personal, healing, and transformative. Several writers have commended Lorde on the relatability of her poems, giving the reader a deeply personal lens to her nuanced life, while simultaneously being able to bring healing through the breaking of silences. In the article "Of Sensual Matters: On Audre Lorde's "Poetry is not a Luxury" and "Uses of the Erotic", Roderick A. Ferguson argues that "For Lorde, poetry was a way to enact an intimate scrutiny needed for personal and social transformation, a way to critically engage the self to set the stage for new interventions and articulations" (296). I bring attention to Ferguson's article to highlight how, for example, trans people who may find it difficult to break these silences may find solace through both reading and creating poetry. In fact, Lorde's poem “A Litany for Survival", breaks from the reader and writer dichotomy by breaking personal silences, while also creating the space for others to do the same. Lorde writes; and when we speak we are afraid our words will not be heard nor welcomed but when we are silent we are still silent (Collected Poems 256) Different from the prose of an essay or the conventional tone of an academic article, Lorde's poetry adds a layer of emotion, empathy, and soul-shaking when it comes to breaking free from our silences. Particularly resonating and impactful is the final stanza of the poem, in which she states "so it is better to speak / remembering / we were never meant to survive" (256). In the midst of tragedies like the Orlando Pulse shooting, as well 
as the daily murders of transgender women of color, Lorde reminds her audience of what she refers to in "The Transformation of Silence into Action" as living in the "mouth of the dragon we call America" (Sister Outsider 42). Being alive as a trans person, particular a trans woman of color, is already an act of radical resistance when living in a heteronormative society that tries to shred LGBTQ lives. When we acknowledge that the validity of our identities, being in the world as ourselves, depends on our vulnerability, then such vulnerability becomes our strength. In referencing bell hooks' book All About Love: New Visions, Janet Mock invokes this vulnerability in relation to trans people and them sharing their stories, as hooks states "Sometimes people try to destroy you, precisely because they recognize your power - not because they don't see it, but because they see it and they don't want it to exist" (Mock 254). Lorde through her poetry is able to convey hooks' and Mock's message, highlighting the power of one's vulnerability in ways that non-poetic language may not have access to.

Part of dismantling the barriers that trans women face is developing compassionate, interdependent communities that allow for the identities of trans people to flourish. When a trans person chooses to tell their story and break the silences, Mock states that it is not merely an act of bravery, but a declaration that can lead to lead to "love, understanding, transcendence, and community". Writers such as Angela Davis make the case for trans liberation, intersectionality, and community support within feminism in her book Freedom is a Constant Struggle, in which she states "Most importantly if the intersectionality of struggles against racism, homophobia, and transphobia is minimized, we will never achieve significant victories in our fight for justice" (89). Similarly, feminist theorist Judith Butler calls for a structure of support for 
trans people, stating in an interview with the activist website TransAdvocate "[N]othing is more important for transgender people than to have access to excellent health care in trans-affirmative environments, to have the legal and institutional freedom to pursue their own lives as they wish, and to have their freedom and desire affirmed by the rest of the world." Long before contemporary feminism became more inclusive towards the experiences of trans women, however, Lorde began the project of collective liberation. After she tells her audience that their silences will not protect them, in that same essay Lorde clarifies that does not mean that the individual act of breaking a silence, such as coming out as queer or transgender, will necessarily ensure in collective liberation. Rather, Lorde states that in finding comfort in speaking out about our oppressions, communities of people that share similar experiences are imperative. In acknowledging community, Lorde states that "The decision to build and maintain ourselves and our communities together and to recognize and solve our problems together" (Sister Outsider 43). Liberation therefore, according to Lorde, ceases to be merely about individual freedom, but about an ethical responsibility to care for one another. In fact, in her essay “The Master's Tools Will Not Dismantle the Master's House”, Lorde's insistence on building inclusive communities is further reinforced by her statement, "Without community there is no liberation, only the most vulnerable and temporary armistice between an individual and her oppression. But community must not mean a shedding of our differences, nor the pathetic pretense that these differences do not exist" (Sister Outsider 112). What separates Lorde's feminism from that of other radical feminists, such as Mary Daly and her fellow academics at that time, is that Lorde's project was not 
concerned with homogenizing a singular idea of woman (straight, white, upper-class, etc), but a radical dismantling of patriarchal violence at its various intersections.

In spite of Lorde's interests in dismantling patriarchy, however, she does not attribute femininity to be at odds with feminist identity. Lorde's reclamation of the feminine marks an important distinction from other radical feminists, who view oppression against women of the basis of biological sex, but view establishing gender as a replication of patriarchal hierarchy. To Lorde, the feminine is not the problem, but rather, the patriarchal system which puts masculinity in hierarchical opposition to femininity. I want to draw particular attention to Lorde's reclamation of the feminine and its importance in the essay "Poetry is not a Luxury". In relation to poetry as a mechanism for liberation, Lorde writes, "Within these deep places, each one of us holds an incredible reserve of creativity and power, of unexamined and unrecorded emotion and feeling. The woman's place of power within each of us is neither white nor surface; it is dark" (Sister Outsider 37). My intent is not to say that femininity does not have its problematics, but that as Lorde does in her essay, redefines and elevates it from the patriarchal constitution of male domination. In referring to femininity, I also want to highlight that femininity can be defined in terms of the conventional tropes associated with the performance of it, such as wearing jewelry and make-up. When these are imposed unto women and others, femininity can become an agent of toxicity. However, as Mock argues in her memoir, femininity can also be "more than just adornments; they were extensions of me, enabling me to express myself and my identity. My body, my clothes, and my makeup are on purpose, just as I am on purpose (147)". Meaning that the femininity which is selfconstructed by oneself, radically differs from the femininity that people who hold cis, 
white, and male identities have the power to normalize. Femininity then can also be a matter of compassion, just as it can be a matter of strength. For when one is allowed the freedom to flourish in our ways of relating and understanding the world, as opposed to being imposed one essential understanding of the world, then identity becomes a matter of validating the inner most feelings of how an other lives. A call to acknowledge the ways of being of others, in which everyone should have the power to construct as an experience that is most profoundly their own. In "Uses of the Erotic", Lorde validates the profundity of one's sense of constructed identity that is reclaiming as opposed to imposing, stating "For not only do we touch our most profoundly creative source, but do that which is female and self-affirming in the face of a racist, patriarchal, and anti-erotic society" (Sister Outsider 59).

For the trans women who have been shamed and denied their femininity, Lorde's words of the feminine being in each of us through the erotic and poetry is affirming. Femininity, in accordance to Lorde, is not reliant on the various societal norms that are imposed on women, particularly trans women, in order to "pass" and not be subjected to violence. A trans woman can tap into her most inner self and declare womanhood, and not be policed by the attributes of toxic femininity, i.e. the imposition to perform gender in binary terms in order to survive in a world that punishes transgression. Which is why I argue that Lorde, according to trans women like Mock, has been essential in the process of rediscovering femininity as constant state of breaking boundaries of the patriarchy, and reclaiming what has been branded as "weak" or "emotive" (Redefining Realness 16). That is not to say that femininity can only be defined in terms of the spiritual, emotional, 
and nurturing. In her poems, for example, Lorde celebrates various manifestations of womanhood. In the poem “A Woman Speaks", Lorde states;

I have been woman

for a long time

beware my smile

I am treacherous with magic

and the noon's new fury" (Collected Poems 234)

The language of the poetry redefines femininity as having existed long before contemporary understandings, as bell hooks would describe as "white supremacist capitalist patriarchy" (belonging 8). Lorde then proceeds to use cultural associations related to the feminine, such as magic, but invokes language that puts the feminine in a position of power through words such as "treacherous", "beware", and "fury". By the end of the poem, Lorde simultaneously challenges the idea that womanhood has to be attributed to white models, which construct a particular type of femininity. Lorde states, "I am / woman / and not white" (Collected Poems 234). Lorde acknowledges the multiplicity of womanhood and its relation to femininity, and in doing so, creates a space where femininity, or the traits attributed to its construction, can be redefined to radically defy patriarchal notions of domination.

Both Morrison and Lorde, in various ways, hold contemporary life-saving importance in the lives of peoples who actively experience marginalization. In fact, organizations like "The Audre Lorde project", which is dedicated towards the embetterment of LGBTQ youth were inspired and built from Lorde's vision. By highlighting how both acknowledging difference, while simultaneously allowing for 
oneself to have the autonomy to create identity in a world that actively tries to strip marginalized peoples of establishing themselves, Morrison and Lorde inspire many to continuously challenge and question who gets to define, and what violence looks like against those that are not encompassed by definitions grounded in white supremacist patriarchy. I can say that in my experiences, as a latinx trans woman, reading Lorde has encouraged me to break my silences and start living my truth. As part of my environmental activism with the Sierra Student Coalition, I've begun to share Lorde poetry's with high school youth, many are profoundly moved by the power of her language. I've seen others come to tears by reading "A Litany for Survival”, finding strength in the vulnerability of sharing how they've survived the various injustices they face daily. I can also say that reading Morrison, still reminds me of the material pervasiveness of white supremacy, and that continuously untangling oppressive ideologies, as Angela Davis would argue, is a constant struggle. For trans women of color like Janet Mock, establishing identity has not come without monumental amounts of opposition that often lead to the system eradication of black trans lives. I hope that by reading the poetry, essays, and theories of Lorde, as well as the literature of Morrison and Mock, many others can access their nourishment. 


\section{BIBLIOGRAPHY}

Agusti, Clara Escoda. "The Relationship between Community and Subjectivity in Octavia E. Butler's Parable of the Sower." Extrapolation, vol. 46, no. 3, 2005, pp. 351-359.

Buell, Frederick. “Global Warming as Literary Narrative.” Philological Quarterly, vol. 93, no. 3, 2014, pp. 261-294.

Butler, Judith. Undoing Gender. Routledge, 2004.

Butler, Octavia E. Parable of the Sower. Warner, 2000.

---. Parable of the Talents. Warner, 2000.

Canavan, Gerry. "Making America Great Again with Octavia Butler." Illinois Press Blog, 11 Nov. 2016, http://www.press.uillinois.edu/wordpress/?p=21211. Accessed 1 Dec. 2016.

Canady, V. A. (2016), New York advocates push bill to prohibit conversion therapy. Mntl. Hlth.Wkly., 26: 3-4. doi: 10.1002/mhw.30655

Carby, Hazel V. Reconstructing Womanhood: The Emergence of the Afro-American Woman Novelist. Oxford UP, 1987.

Cronon, William. Rethinking the Human Place in Nature. W. W. Norton \& Co, 1995.

Davis, Angela Y., and Frank Barat. Freedom Is a Constant Struggle: Ferguson, Palestine, and the Foundations of a Movement. Haymarket, 2016.

Gaard, Greta. "Green, Pink, and Lavender: Banishing Ecophobia through Queer Ecologies.” Environment \& Ethics, vol. 16, no. 2, 2011, pp. 115-126.

Goldstein, Joseph. "Alt-Right Gathering Exults in Trump Election With Nazi-Era." The New York Times, 20 Nov. 2016, https://nyti.ms/2k4xJaa. Accessed 1 Dec. 2016.

Goodman, Amy, and Juan Gonzales. "Science Fiction Writer Octavia Butler on Race, Global Warming and Religion." Democracy Now!, 11 Nov. 2005, democracynow.org/2005/11/11/science_fiction_writer_octavia_butler_on. Accessed 1 Dec. 2016.

Hooks, Bell. Ain't I a Woman: Black Women and Feminism. South End, 1981.

Hutchings, Kevin D. Romantic Ecologies and Colonial Cultures in the British Atlantic World, 1770-1850. McGill-Queen's UP, 2009. 
Jackson, Sandra. The Black Imagination, Science Fiction, and the Speculative, edited by July Moody-Freeman, Routledge, 2011.

Jos, Philip H. "Fear and the Spiritual Realism of Octavia Butler's Earthseed." Utopian Studies, vol. 23 no. 2, 2012, pp. 408-429.

Lorde, Audre. The Collected Poems of Audre Lorde. Norton, 2000.

---. The Cancer Journals. Aunt Lute Books, 1997.

---. Sister Outsider: Essays and Speeches. Crossing, 2007.

McCaffery, Larry. Across the Wounded Galaxies: Interviews with Contemporary American Science Fiction Writers. U of Illinois, 1990.

Melzer, Patricia. "All that you touch you change": Utopian Desire and the Concept of Change in Octavia Butler's Parable of the Sower and Parable of the Talents." Femspec, vol 3, no.3, 2002, pp. 31-52.

Miller, Jim. "Post-Apocalyptic Hoping: Octavia Butler's Dystopian/Utopian Vision." Science Fiction Studies, vol. 25, no. 2, 1998, pp. 336-360.

Mock, Janet. Redefining Realness: My Path to Womanhood, Identity, Love \& so Much More. Atria, 2014.

More, Thomas. Utopia, edited by George M. Logan and Robert M. Adams, Cambridge University Press, 2002.

Morton, Timothy. "Guest Column: Queer Ecology.” PMLA, vol. 125, no. 2, 2010, pp. 273-282

Muñoz, José Esteban. Cruising Utopia: The Then and There of Queer Futurity. New York UP, 2009.

Newsome, John. "Pope Warns of 'ideological Colonization' in Transgender Teachings." CNN, 4 Oct. 2016, cnn.com/2016/10/02/world/pope-transgender-comments. Accessed 1 Dec. 2016.

Nixon, Rob. Slow Violence and the Environmentalism of the Poor. Harvard UP, 2011.

Obourn, Megan. “Octavia Butler's Disable Futures.” Contemporary Literature, vol. 54, no. 1,2013 , pp. 109-138.

Perez-Pena, Richard. "College Classes Use Arts to Brace for Climate Change." The New York Times, 31 Mar. 2014, https://nyti.ms/2jN4Diw. Accessed 15 Nov. 2016. 
Stanley, Eric A., and Nat Smith. Captive Genders: Trans Embodiment and the Prison Industrial Complex. AK, 2011.

Stillman, Peter G. "Dystopian critiques, utopian possibilities, and human purposes in Octavia Butler's Parables. (Essays on Octavia Butler)." Utopian Studies, vol. 14, no. 1,2003 , pp. $5+$.

Stoll, Mark. "How Pope Francis Helped Awakened a Deep Religious Tradition for Care for the Environment." The Washington Post, 25 Sept. 2015, www.washingtonpost.com/news/acts-of-faith/wp/2015/09/24/how-pope-francishelped-awaken-a-deep-religious-tradition-for-care-for-theenvironment/?utm_term=.3c4d1fe6175a. Accessed 15 Nov. 2016.

Thibodeau, Amanda. “Alien Bodies and a Queer Future: Sexual Revision in Octavia Butler's"Bloodchild" and James Tiptree, Jr's "White Delicate Mad Hands."” Science Fiction Studies, vol. 39, no. 2, 2012, p. 262-282.

Tinsley, Natasha. Black Atlantic, Queer Atlantic: Queer Imaginings of the Middle Passage. Duke University Press, 2008.

Welter, Barbara. "The Cult of True Womanhood: 1820-1860." American Quaterly, Vol. 18, No. 2, 1996, pp. 151-174. 